\title{
CONCEPTUAL METAPHOR A FAMILY IS A HOUSE IN VIETNAMESE
}

\author{
$\mathrm{Vu}$ Hoang Cuc \\ Tay Nguyen University \\ 567 Le Duan, Buon Ma Thuot, Dak Lak, Vietnam \\ (PhD student at University of Social Sciences and Humanities, \\ Vietnam National University - Ho Chi Minh City) \\ Received 17 March 2020 \\ Revised 24 April 2020; Accepted 21 November 2020
}

\begin{abstract}
The article analyzes the conceptual metaphor A FAMILY IS A HOUSE in Vietnamese to explore the ways Vietnamese people conceptualize family via the domain of HOUSE. To fulfill the research objectives, the article uses the theory of conceptual metaphors and other fundamental concepts of Cognitive linguistics to establish and analyze the mappings from the source domain HOUSE to the target domain FAMILY. The research findings show that Vietnamese people use the house to conceptualize the family as a place to shelter and protect each member. Besides, different parts of the house including the roof, rooftop, pillar, space and the activities of building, destroying the house are also used to express the ways Vietnamese people perceive the roles of the father, husband, family relationships, establishment and breakup and protection of the family. The use of the house to express views of the family demonstrates distinctive cultural features of the Vietnamese people.
\end{abstract}

Keywords: conceptual metaphor, mapping, family, house, Vietnamese.

\section{Introduction}

1.1. Conceptual metaphor is the way to express people's thought. It shows the ways people see things in their life based on their embodiment experiences. Therefore, exploring conceptual metaphors enables us to discover the uniqueness in the thought and cognition mechanism of humans.

1.2. In Vietnamese Dictionary, family is defined as "tập hợp người cùng sống chung thành một đơn vị nhỏ nhất trong xã hội, gắn bó với nhau bằng quan hệ hôn nhân và dòng máu, thường gồm có vợ chồng, cha mẹ và con cái” (Hoàng Phê, 2010, p. 496) (a gathering of people living together in the smallest unit in the society, bonding with each other by marriage and blood ties, often including husband and wife, parents and children). Similarly, in Cambridge dictionary (n.d.), the family is defined as "a group of people who are related to each other, such as a mother, a father, and their children". Our family is where we were born and brought up both physically and sentimentally. Our family consists of our beloved people with close relationships; it is the place where we can share and get our life difficulties shared by others. For these reasons, any one of us highly values our own families; whenever possible, we try to gather with our families to enjoy emotional warmth.

The conceptual metaphor A FAMILY IS A HOUSE is one of many conceptual metaphors about the family of Vietnamese people. Investigating these metaphors gives us an interesting insight into the concept of the family based on the embodiment experiences of the houses; it also helps us to discover distinctive cultural features of Vietnamese people via their thought of the family.

\footnotetext{
“Tel.: 0934997712, Email: hoangcucbmt@gmail.com
} 


\section{Literature review}

The application of conceptual metaphor theories into the research of linguistics in literature and life has brought about considerable achievements, as can be seen in the gigantic number of journal articles and research projects in the world since the conceptual metaphor theory was introduced by Lakoff and John in 1980. However, in a narrower scale, researchers in the world as well as in Vietnam have not paid adequate attention to the study of metaphors of families in different languages.

According to the author's review, as the target domain in conceptual metaphors, FAMILY has been used in just some political discourses in presidential elections in the US; for example in several conceptual metaphorical expressions about family as shown in Conceptual Metaphors of Family in Political Debates in the USA (Adams, 2009). Upon surveying 104 debates in different forums between candidates in their races to political agencies, the article found some conceptual metaphors about the roles of the family (nuclear family and family in general), which are used in the election campaigns of the candidates, for instance, A NUCLEAR FAMILY IS MASTERY or NUCLEAR FAMILIES ARE CANDIDATES.

In Vietnam, up to now, there has been no journal article nor research project on conceptual metaphors of the family.

\section{Research methods}

The research sample was collected and analyzed to answer the following research questions: (1) In the conceptual metaphor A FAMILY IS A HOUSE, which aspects of the source domain HOUSE are mapped to the target domain FAMILY? (2) What do these mappings show about the thought and cognitive ways of Vietnamese people about the family?

The sample used in this article includes idioms, proverbs and extracts from some Vietnamese literature works which portray the family. The linguistic forms in the sample are translated literally into English to provide a genuine view of the mappings from the aspects of the source domain HOUSE to the target domain FAMILY.

The conceptual metaphor A FAMILY IS A HOUSE is analyzed on the basis of conceptual metaphor theory, including the definition, features and grounding of conceptual metaphor. These concepts are summarized in the following parts.

\section{Theoretical grounds}

Conceptual metaphor is defined as "understanding one conceptual domain in terms of another conceptual domain" (Kövecses, 2010, p. 4). Each conceptual metaphor consists of two domains: source domain and target domain. The latter is understood in terms of the former. The source domain is usually concrete, specific or physical while the target domain tends to be abstract and less delineated. The two domains are related to each other in the mode of TARGET DOMAIN IS SOURCE DOMAIN. According to cognitive linguistics, there is a one-way mapping from the source domain to the target domain; the reverse mapping from the target domain to the source domain does not exist. The source domain includes many aspects, but not all of them are mapped to the target domain. It is common that just some aspects are mapped to the target domain. In other words, mappings are only partial from the source to the target domain.

Each conceptual domain in conceptual metaphors is a systematic organization of 
human experiences (Kövecses, 2010). These experiences are referred to as embodiment. "In its broadest definition, the embodiment hypothesis is the claim that human physical, cognitive, and social embodiment ground our conceptual and linguistic system" (Rohrer, 2007, pp. 25-47). Human experiences are not just the experiences about features and processes of objects and events in the natural world; not just experiences about social relationships and their characteristics but experiences about our own physiobiological, psychological, intellectual activities as well. Experiences arising from human interactions with nature, society and our own bodies are the ingredients for humans to establish concepts which build up conceptual metaphors. In other words, "the structure of our spatial concepts emerges from our constant spatial experience, that is, our interaction with the physical environment" (Lakoff and Johnson, 1980, pp. 56-57). As such, the interactions of human bodies with our living environment have provided us with experiences which, in their turn, become "materials" for us to create concepts to structure and interpret things in our life, then to deliver them in metaphorical expressions.

So on what grounding do people use their own experiences to conceptualize objects in their life? The answers are: Correlations in Experience and Perceived Structural Similarity are the biggest motivations of conceptual metaphors (Kövecses, 2010).

Correlations in Experience is one of the motivations of conceptual metaphors. It is important to note that correlations are not similarities. Correlations refer to the shared features between the two elements while similarities involve the co-occurrence of the two elements. In other words, correlations refer to two events that accompany each other constantly and repeatedly in experiences of humans. It is the correlations that motivate people to create some conceptual metaphors.

Kövecses (2010) explains this motivation as follows:

If event E1 is accompanied by event E2 (either all the time or just habitually), E1 and E2 will not be similar events; they will be events that are correlated in experience. For example, if the event of adding more fluid to a container is accompanied by the event of the level of the fluid rising, we will not say that the two events (adding more to a fluid and the level rising) are similar to each other. Rather, we will say that the occurrence of one event is correlated with the occurrence of another. This is exactly the kind of correlation that accounts for the conceptual metaphor MORE IS UP. (pp. 79-80)

\section{Besides Correlations in Experience,} Perceived Structural Similarity is another foundation for the establishment of conceptual metaphors. Perceived structural similarity is not the objective pre-existing similarities between the two events. Rather, they are nonobjective similarity that speakers of a language perceive of the two events (Kövecses, 2010). For example, the perceived structural similarity of Vietnamese people about life and river is the grounding for the conceptual metaphor LIFE IS A RIVER in Vietnamese. Vietnamese see life as a river with flows, waterfalls, waves; activities taking place in life are like activities people take in a river, for instance, lênh đênh giũa cuộc đời (flowing in life), cuộc đời của nó lắm thác ghềnh (his life has gone through many waterfalls), cầu cho mọi chuyện xuôi chèo mát mái (wishing everything a smooth sail), sóng gió cuộc đời (life waves), ngụp lặn giũ̃a dòng đòi (swimming against life waves), chói với giữa dòng đời (drowning in life waves) and so on. 
The above theoretical grounds are used in our study, which yields the following findings.

\section{Research findings}

The conceptual metaphor A FAMILY IS A HOUSE is a typical conceptual metaphor of the family in Vietnamese (in comparison with other conceptual metaphors of the family in Vietnamese such as A FAMILY IS A BIRD'S NEST, A FAMILY IS A TREE, A FAMILY IS A COHESIVE UNIT). It reflects the distinctive cognition of Vietnamese people about the structure, durability and functions of the family.

So which experiential basis and embodiment experiences are the motivations for Vietnamese people to use the conceptual domain HOUSE to express their thought of the family?

Just like eating and drinking to maintain subsistence, accommodation is among the fundamental needs of a person. Houses therefore play an essential role to each person. A house not only serves as a shelter to protect us from external adverse impacts but also creates a space for us to live and rest. For these reasons, houses and their features have become a popular source domain in conceptual metaphors. "Both the static object of a house or its parts and the act of building it serve as common metaphorical source domain" (Kövecses, 2010, p. 19). We use our understanding of houses, their parts and features, the acts of building and preserving our houses to conceptualize many objects in the world we are living in.

That Vietnamese people use the target domain HOUSE to conceptualize the family is grounded by this common fact. However, there is another motivation for this conceptual metaphor. Shelters are very important in a water-rice cultivating culture as people can only grow rice and other vegetables once they settle in a location. Therefore, Vietnamese people have a saying "an cư lạc nghiệp" (settle down and thrive), which means only by settling in a specific location can they feel secure to make a living and develop their work. As an inevitable result, to settle in a location, shelters - or houses - are the first factor to care for. People need a house to settle down. Therefore, houses keep a crucial hold in the mind of Vietnamese people. Under the conceptual metaphor theory, an object is chosen as the source domain to conceptualize another domain only when it satisfies the following conditions: appearing first, or having strongest influences, or appearing constantly, or meeting two or three above conditions. With people in an agricultural society, houses satisfy all these three conditions.

In the perception of Vietnamese people, a house has lots of similarities to a family. The similarities appear in various elements, from structure to the process of building and preservation. These are the foundations for the establishment of the conceptual metaphor A FAMILY IS A HOUSE.

In the conceptual metaphor A FAMILY IS A HOUSE, the source domain HOUSE provides knowledge of a house's features such as: having a design; being constructed carefully; having different parts such as ridge, roof, wall, ground, foundation, door, window, stairs, doorstep, paint, lime; having space: inside the house, outside the house, upstairs, downstairs; having different styles: high houses, low houses, 1-storey houses, multi-storey houses, Thairoof houses, etc. However, not all these aspects are mapped to the target domain of 
FAMILY. As one feature of the conceptual metaphor is highlighting and hiding, when a source domain is mapped to a target domain, only some aspects of the target domain are highlighted (Kövecses, 2010). Only some sub-regions in the conceptual domain of "a house" are utilized to structure concepts related to family.

\begin{tabular}{ccc}
\hline $\begin{array}{c}\text { Source domain } \\
\text { (House) }\end{array}$ & $\begin{array}{c}\text { Target domain } \\
\text { (Family) }\end{array}$ \\
\hline House & $>>>>$ & Family \\
House roof & $>>>>$ & Father \\
House pillar & $\gg>>>$ & Husband / father \\
House space (inside, outside, corner, etc.) & $\gg>>>$ & Family relationships, lifestyles \\
Building & $\gg>>>$ & Establishing and keeping family \\
Being damaged (break down / collapse / & $\gg>>>$ & Breakup \\
wreckage, etc.) & & \\
\hline
\end{tabular}

Figure 1. Set of mappings of the conceptual metaphor A FAMILY IS A HOUSE

Seeing the family as a house, Vietnamese people usually use many linguistic forms belonging to the semantic field of houses such as house, roof, foundation, rooftop, pillar, wall, design, construction, leaking, cracks, damage, collapse, etc. to talk about the family:

(1). Việc lớn nhỏ trong nhà đều do cô quyết... Cô mới là rường cột ngôi nhà, chú chỉ là thành phần trang trí. (Nguyễn Quỳnh Hương, 2017, p. 84).

(Every big or small chore in her house has been decided by her. She is the pillar of the house while her husband is just a kind of ornament.)

(2). Chị đã là bà vua trong nhà của mình. Mà vua thì luôn cô độc và... Đã quá xa với thiết kế ban đầu về hạnh phúc của chính chị. (Dạ Ngân, 2015, p. 74)

(She is the female king in her house. The king is always lonely and... It is away from her original design of happiness.)

(3). Đàn bà sống một mình khó lắm... không ra một gia đình. Đàn ông họ có đui què mẻ sứt gì cũng là trụ cột, cái nóc của nhà mình. (Dona Đỗ Ngọc, 2017, p. 63)

(It is difficult for a woman to live alone... not to be a family. A man who is even disabled is the pillar, the roof of her house.)

(4). Vợ tôi bảo: nhà mình nói năng như điên khùng cả. (Nguyễn Huy Thiệp, 2007, p. 107)

("Our house all talk nonsense", said my wife.)

(5). Chị bất thần lật úp xuồng, lúc đó chỉ muốn nhấn chìm mình đi để rửa hết nỗi tủi nhục của người đàn bà mang tiếng giựt chồng. Nghèn nghẹn nước, chị ôm một bên mạn xuồng từ từ chìm lỉm, chợt nhớ lại cái nhà mình từ lâu đã không có nóc, chẳng lẽ chị để nó mất luôn phên, dù mái phên có tồi tàn ủ dột. (Many authors, 2011, p. 128)

(She suddenly turned her boat upside down, just wanting to sink herself to wash away all the shames that she has to suffer from flirting with another woman's husband. Full of tears, she held one side of the boat which was slowly sinking, suddenly thinking about her house whose rooftop had been damaged a long time ago, now she doesn't want to lose its ridge, though the ridge had already torn out.)

(6). Cả nhà mình thu xếp về thăm mẹ một chuyến đi em. (Đỗ Thị Minh Nguyệt, 2013,p. 7) 
(Our house should pay a visit to our mom.)

(7). Nhà vắng người đàn ông trụ cột. (Many authors, 2014, p. 248)

(The house lacks a pillar man.)

(8). Vậy mà hai mảnh đời tả tơi đó chấp lại, mái gia đình chúng tôi đang dột te tua chợt lành bon. (Võ Diệu Thanh, 2016, p. 496)

(When the two weary lives are joined, our seriously leaking roof suddenly gets fixed.)

(9). Dường như bằng cách này bạn giành lấy tình thương của má, khi trót sinh ra dưới một mái nhà đông anh chị em. (Nguyễn Ngọc Tư, 2017, p. 13)

(In that way, you can gain the love from your mom when you are born into a roof with lots of siblings.)

(10). Mày chỉ muốn gia đình chị mày tan nát mới chịu im mồm phải không? (Phạm Thị Ngọc Liên, 2007, p. 141)

(You aren't going to shut your mouth until your sister's family is damaged, are you?)

(11). Những thay đổi trong cuộc sống sôi động ngoài kia từ lâu trở thành vết rạn âm ỉ trong nền tảng của một gia đình. (Nguyên Hương, Trang Hạ \& Nguyễn Thị Thanh Mận, 2014, p. 131)

(The changes in the hustle life outside have caused a permanent crack to the foundation of a family.)

(12). Anh biên kịch tuồng chèo kể vừa mới trong trại tù ra, cả nhà tan nát, vợ bỏ rơi con để đi theo tay thẩm phán. (Nguyễn Ngọc Tư, 2017, p. 129)

(The editor said that when he was released from jail, his house was damaged, his wife had left his children to follow the judge.)

Conceptualizing A FAMILY IS A HOUSE, first of all, Vietnamese people express the views that a family is where people find a shelter which shields and protects them, just like a house which protects people from harmful impacts of their habitats. Besides, we also see that many aspects of the source domain HOUSE are used by Vietnamese people to discuss other aspects of the family. Each aspect of the source domain HOUSE corresponds to another aspect of the family as shown in the set of mappings to create lowerlevel metaphors of the conceptual metaphor A FAMILY IS A HOUSE. They are FATHER IS THE ROOF OF THE HOUSE, HUSBAND/ FATHER IS THE PILLAR OF THE HOUSE, RELATIONSHIPS AND LIFESTYLES OF THE FAMILY ARE THE SPACE OF THE HOUSE, ESTABLISHING AND KEEPING THE FAMILY IS BUILDING A HOUSE, FAMILY BREAKUP IS A DAMAGED HOUSE.

What are the cognitive foundations of lower-level metaphors of the conceptual metaphor A FAMILY IS A HOUSE?

Why is the father conceptualized as a house's roof? Firstly, the roof of the house is considered equally important to its ground by Vietnamese people. When building a house, in addition to organizing a ground-breaking ceremony to ask the God of the Soil for permission, Vietnamese people also hold a roof-building ceremony before they build the roof. This ceremony aims to pray for safety, luck and blessings that will come to the family when they live in that house. As such, in the thought of Vietnamese people, the roof of the house represents the spiritual protection for the family. Secondly, in the house design, the roof is at the top of the house - its highest position. It shields the house from the sunrays and the rain. If the roof is damaged, the inner parts of the house will be gradually damaged under 
the impacts of adverse weather conditions from the environment.

In the meantime, in Vietnamese culture, the father is regarded as the one who has the top power to make important decisions in the family, the one who keeps the family's lifestyles and rules, the one who guides, instructs and educates children. The father is always stricter than the mother. Besides, the father is always the one who protects and shoulders all the difficulties that the family is facing, both physically and spiritually.

Based on the cognitive similarities between the features of the house roof and the characteristics of the father in the family as stated above, Vietnamese people construct the conceptual metaphor FATHER IS THE ROOF OF THE HOUSE.

(13). Không có đàn ông trong nhà rõ ràng là nhà không có nóc ấy chứ. (Phan Ngọc Diễm Hân, 2012, p. 131)

(Without a man in the house, the house doesn't have its roof.)

(14). Anh là cái nóc nhà như quy ước, như định nghĩa nhưng em vẫn nhiều lần cảm thấy mình bị phơi ra một mình với sinh kế và mọi thứ không tên giữa đất trời giông gió nắng mưa. (Dạ Ngân, 2010, p. 145)

(You are the roof of the house as usually defined, but for most of the time I feel that I am exposed to livelihoods and many unnamed tasks amid the stormy and rainy weather.)

(15). Không cha nhà dột, cột xiêu. (Idiom)

(Without father, the house roof is leaking, the pillar is sloping.)

(16). Con có cha như nhà có nóc.

Con không cha như nòng nọc đứt đuôi. (Folk verses)
(A child with father is like a house with a roof.

A child without father is like a tadpole without a tail.)

If a house does not have a roof for protection, its inner parts will be damaged; as a consequence, the house will collapse. Similarly, if a family does not have a father, it will not survive difficulties (example (15)).

Children without father are often referred to as children of a house without a roof with critical implications:

(17). Con không cha như nhà không nóc. (Idiom)

(A child without father is like a house without a roof.)

(18). Tình yêu sâu sắc đầu tiên của anh chuẩn bị đi đến hôn nhân thì người ta bĩu môi ngăn cản: "Nó là thằng nhà không nóc" (Quang Trinh, 2011, p. 252)

(His first deep love almost led him to a marriage until people prevented it for a critical reason: "He's a guy from a house without a roof').

This conceptualization may stem from the experiential similarities between the two events: a house without a roof and children without a father. A house without a roof may result in the damages to other inner parts; likewise, children without a father may not receive good education (as mentioned above, Vietnamese people believe that in the family the father takes main responsibilities for teaching children). In the traditional Vietnamese society, people tend to think that children with fathers are those who are well educated (like in example (16)). Vice versa, children without father - children of single moms - are often regarded as those who do not receive good education, even those who 
lack proper education; consequently, they often suffer from critical looks from other community members as "children without father".

Children are taught by their father, so if the father does not have good ethics, his children may take after. Vietnamese people often use a saying of "Nhà dột tù nóc dột xuống", which literally means a house which leaks from its roof.

Besides the roof, the pillars of a house are also used by Vietnamese people to describe the roles of the man in the family. In the conceptual metaphor A FAMILY IS A HOUSE, the aspects of the pillar of the source domain HOUSE are mapped to the target domain FAMILY to conceptualize the characteristics of the husband/father, thus creating the conceptual metaphor HUSBAND/ FATHER IS THE PILLAR OF THE HOUSE. It is apparent that a pillar is made of concrete and firm materials in a cylindrical or square form, erected and fixed in one position to bear the weight of the house, making the house stable. The pillar is said to be one of the most important parts of the house. These aspects correspond to the roles of the husband/father in the family. In their daily life, Vietnamese people always describe the husband/father as the pillar of the family.

(19). Nhà vắng người đàn ông trụ cột. (Many authors, 2014, p. 248)

(The house lacks a pillar man.)

(20). Chị bẽn lẽn bên người chồng trụ cột. (Dạ Ngân, 2015, p. 72)

(She looks shy when sitting next to her pillar husband.)

(21). Có lẽ bà muốn nhường việc trả lời cho người giữ vai trò trụ cột gia đình, điều mà bất kỳ người vợ nào cũng kỳ vọng nơi chồng. (Bích Ngân, 2010, p. 162)

(She may want to give the rights to answer to the person with the pillar role in the family - a thing which any wife expects from their husband.)

(22). Chàng không và sẽ không bao giờ có sức làm trụ cột gia đình mà nàng thì lại ngại những người đàn ông như thế. (Nguyễn Thị Thu Huệ, 2004, p. 141)

(He does not and will never have sufficient strength to become the family pillar while she is afraid of such men.)

(23). Không biết tới chừng nào chị mới làm được như má, khiến cho người đàn ông của gia đình trong cùng khổ vẫn thấy mình là trụ cột. (Nguyên Hương, 2014, p. 302)

(She doesn't know when she can do like her mom - a person who can make the man in the family still feel like they are a pillar even in extreme difficulties.)

In a Vietnamese family, the husband is always thought of as the one who takes financial responsibility, who makes a living to raise the entire family, who at the same time serves as a spiritual support to his wife and children amid all life challenges. If a husband cannot fulfill these expectations, he is often looked down on by others and considered as not deserving to be called a man.

Besides the roof and pillar, a house space is also used by Vietnamese people to conceptualize the family. In the conceptual metaphor A FAMILY IS A HOUSE, the aspects of "a house space (inside, outside, at the corner, etc.)" of the source domain HOUSE are mapped to the aspects of "relationships and lifestyles of a family" in the target domain FAMILY to create the conceptual metaphor RELATIONSHIPS AND LIFESTYLES OF THE FAMILY ARE THE SPACE OF THE 
HOUSE. Vietnamese people believe that the relationships and lifestyles of a family create a (spiritual) space that embraces all family members, just like the way a house accommodates people. Therefore, a family has the space "inside", "outside" and "at the corner"; light and dark corners; as well as high and power places.

(24). Thế cho nên mới trong ấm ngoài êm. Nhà người ta như thế thì chú Nam cứ để như thế. (Phạm Thị Ngọc Liên, 2015, p. 42)

(That's why it's warm inside, harmonious outside. Their house is going that way; Nam should keep it that way.)

(25). Bố cô qua đời, sự mất mát lan tỏa trong gia đình cô. (Trần Thị Ngọc Lan, 2008, p. 217)

(When her mom passed away, the loss feelings spread across her family.)

(26). Không khí trong gia đình hôm nay thật là vui. (Hồng Thủy, 2010, p. 102)

(The atmosphere inside the family is joyful today.)

(27). Một người con gái sinh ra và lớn lên trong một gia đình trí thức Hà Nội. (Nguyễn Duy Năng, 2012, p. 13)

(She was born and grows up in a welleducated family in Hanoi.)

(28). Tự dưng tôi thấy mình ân hận ghê gớm. Ân hận vì đã bước vào gia đình nó, đã giành mất tình thương của ba nó. (Nhiều tác giả, 2011, p. 155)

(I suddenly feel regretful. I am regretful of entering his family and gaining his father's affection.)

(29). Bạn đã chẳng hề biết gì về họ cả. Bạn làm sao có thể bước chân vào gia đình ấy. (Trang Hạ, 2014, p. 143)
(You didn't know anything about them. How could you enter their family?)

(30). Mẹ tôi đã van xin ông rất nhiều nhưng ông vẫn một mực từ tôi ra khỏi gia đình. (Trần Đức Tĩnh, 2014, p. 248)

(My mom begged him a lot but he insisted on drawing me out of the family.)

(31). Tôi không thích cái lối kể về những ngóc ngách tối tăm của gia đình một cách lạnh lùng như Hà. (Phan Thị Vàng Anh, 1994, p. 107)

(I don't like the cold way Ha talks about dark corners of her family.)

(32). Thằng út bị dồn vào chân tường, rơi vào hố ghẻ lạnh của chính gia đình mình. (Vũ Đình Giang, 2014, p. 278)

(The youngest child is driven into the corner, falling into the estrangement hole in his own family.)

(33). Tôi phải quen với những vị trí mới trong gia đình. (Nguyên Hương, Trang Hạ \& Nguyễn Thị Thanh Mận, 2014, p. 128)

(I have to get accustomed to the new places in the family.)

Family relationships and lifestyles are of great significance. They represent the spiritual life of a family. They are like a space that embraces all the family members. People can enter, get out of, stay inside, stay outside, see the corners or stay in a certain place in the family. When someone enters a family, he or she is starting a relationship and getting accustomed to the lifestyle of that family (examples (28), (29)). When someone gets out of a family, he or she has quit the relationships with that family's members and is no longer considered its member (example (30)). Staying inside/outside a family means keeping/quitting the family relationships 
(examples (24), (25), (26), (27)). These relationships have light and dark corners, high and low places like in a house space (examples (31), (32)). In the family relationships, every member has different places like the places of different parts in a house's structure (example (33)). Describing the family relationships and lifestyles like the spatial structure of a house shows the close emotional ties between family members as well as the lifestyles of the family.

Among various activities related to the house, Vietnamese people only use building and damaging to conceptualize the family. Building is utilized to talk about the establishment while damaging is used to mention family breakup.

In the conceptual metaphor A FAMILY IS A HOUSE, the aspect "building" of the source domain HOUSE is mapped to the aspect "establishing and keeping the family" of the target domain FAMILY to create the conceptual metaphor ESTABLISHING AND KEEPING A FAMILY IS BUILDING A HOUSE. Vietnamese people use the words referring to the building of houses to talk about the establishment and preservation of the family: building, constructing.

(34). Ông xây nên một mái gia đình. (Ka Bình Phong, 2017, p. 285)

(He builds a family's roof.)

(35). Chồng nàng đã không biết quý trọng công sức mà nàng xây đắp cho gia đình. (Nhiều tác giả, 2011, p. 118)

(Her husband doesn't value the efforts she has made to build the family.)

(36). Chúc cháu sớm tìm được người thích hợp để xây dựng gia đình. (Phạm Thị Ngọc Liên, 2015, p. 193)

(I hope that you will soon find a suitable partner to build your family.)
(37). Có những người phụ nữ lấy ai cũng dựng nên một gia đình hạnh phúc. (Trang Hạ, 2014, p. 98).

(There are some women who can construct a happy family with whoever men they get married to.)

(38). Gia đình của mình mình trân trọng vun đắp. (Phan Ý Yên, 2016, p. 6)

(We treasure our family by building it.)

Building is by no means a simple task. As defined in Vietnamese dictionary (Hoàng Phê, 2010), building is "creating an architectural work according to a specific plan" (p. 1463). It requires careful and long-lasting work. By conceptualizing the establishment of a family as building a house, Vietnamese people wish to emphasize the hard and energy-consuming work that is needed to establish a family.

The aspect "being damaged" of the source domain HOUSE corresponds to the aspect "breakup" in the target domain FAMILY to create the conceptual metaphor FAMILY BREAKUP IS A DAMAGED HOUSE. Words referring to the "damages" to the house such as swaying, cracking, collapse, damages, destruction, wreckages, etc. are used to talk about the breakup of a family.

(39). Gia đình tôi bắt đầu nghiêng ngửa, hay nó đã rạn nứt từ lâu rồi mà bộ óc $\mathrm{u}$ mê của tôi chẳng nhận thấy. (Nguyễn Xuân Khánh, 2019, p. 68)

(My family starts to sway, or it has cracked for a long time but my deafmind does not realize.)

(40). Ba má bỏ nhau, gia đình tan nát. (Many authors, 2014, p. 114)

(When my parents divorce, my family is damaged.)

(41). Tui sẽ làm tan nát gia đình họ. (Võ Thị Xuân Hà, 2006, p. 229) 
(I will destroy their family.)

(42). Một tình bạn phản bội, một gia đình đổ nát... đều là bất hạnh cá nhân. (Phan Ý Yên, 2016, p. 13)

(A friendship betrayal, a family destruction... all are personal mishaps.)

(43). Anh cũng yêu em nhưng anh không thể phá võ̃ cuộc sống gia đình được. (Nguyễn Thị Thu Huệ, 2004, p. 484)

(I love you too but I cannot destroy my family life.)

(44). Tại sao gia đình đang tốt đẹp như thế, đang đầm ấm như thế mà ba nỡ phá hỏng? (Phạm Thị Ngọc Liên, 2007, p. 31)

(Why can you destroy a family which is so beautiful and cozy, dad?)

(45). Lý do gì đã dẫn đến sự đổ võ̃ của gia đình cô? (Từ Thiết Linh, 2004, p. 9)

(What caused her family's collapse?)

(46). Sự tan võ̃ của gia đình đã làm bà suy nhược thần kinh. (Many authors, 2014, p. 122)

(Her family's collapse has resulted in her neurasthenia?)

A house is a solid object with many parts, when it is damaged, there will be a massive collapse, its parts will fall apart and be destroyed. The force that causes the damages to the house must be immensely strong. Therefore, the expressions the family collapses / is damaged / is destroyed, etc. not only depict the breakup of the family but also show the spiritual injuries that family members have to suffer. When a family breaks up, its members are hurt, as each part the house is broken into pieces. At the same time, these linguistic expressions also imply that the causes of family breakup have put heavy pressure on each member, hurting them emotionally; moreover, when a family is destroyed, its builders must feel very sad and regretful because just like building a house, it takes a long time and lots of efforts to build up a family. Most importantly, the message that Vietnamese people want to convey when conceptualizing FAMILY BREAKUP IS A DAMAGED HOUSE is the affirmation about the roles of the family as a shelter to each member. Losing family is like losing a house, losing a shelter to each person. The collapse of a family due to marriage failure really has negative impacts on each member.

Based on the metaphor A FAMILY IS A HOUSE, we can find the derivative metaphor A HAPPY FAMILY IS A WARM HOUSE.

(47). Người ta sinh ra đâu ai chọn bố, chọn mẹ, chọn mái ấm hay mái rách cho mình được. (Võ Thu Hương, 2012, p. 159)

(A person cannot choose his father, mother, warm house or cold house for himself.)

(48). Mỹ đã coi đây là mái ấm gia đình. (Hồng Thủy, 2010, p. 96)

(Mỹ has considered this place her warm house.)

(49). Anh từng hứa cho chị mái ấm nhưng đến cả mái nhà còn lo chưa xong. (Thái Cường, 2018, p. 36)

(He promised to bring her a warm house but now cannot even create a roof.)

(50). Em hỏi anh, anh định kéo dài quan hệ giữa $\mathrm{em}$ và anh đến bao giờ? Người đàn ông nhún vai: điều này em tự biết. Cô bảo: Em cần một mái ấm. (Võ Thị Xuân Hà, 2009, p. 6)

("Tell me, you plan to maintain our relationship for how long?" The man shakes his shoulder: "You know it by yourself." She answers: "I need a warm roof".) 
The conceptual metaphor A HAPPY FAMILY IS A WARM HOUSE is a complex metaphor with the presence of metonymy. It has the combination of the conceptual metonymy THE HOUSE ROOF IS A HOUSE (where part stands for the whole) and the conceptual metaphor HAPPINESS IS WARMTH. In its turn, HAPPINESS IS WARMTH is the lowerlevel metaphor of the conceptual metaphor POSITIVE EMOTIONS ARE WARMTH. The conceptual metaphor POSITIVE EMOTIONS ARE WARM TEMPERATURES stems from people's physiologic embodiment about warm temperatures. Warmth is different from heat. Heat may be unbearable while warmth brings us comfort and relaxation. Food will taste better when it is kept warm, a warm hand will make holders feel intimate and peaceful, a warm house will help us stay healthy, etc. From experiences of the impacts that warm temperatures place on our bodies, we usually use warm feelings to describe things that bring us comfort: $\breve{A n}$ vào thấy ấm bung (feel warmer after eating), nghe ấm trong $d a$ (feel warm in our soul), nghe ấm lòng (feel warm in our heart), cuộc sống ấm no (a warm full life), cuộc sống ấm êm (a warm life), no corm ấm cật (full stomach, warm feeling), etc. Among different emotions of humans, love, like, affection, happiness, delight, enjoyment, etc. are those which bring comfortable feelings to recipients. It is similar to the feelings that warm temperatures bring to us. These similarities motivate the conceptual metaphor POSITIVE EMOTIONS ARE WARM TEMPERATURES. Vietnamese people have common saying: sụ ấm áp của tình ngườ (the warmth of human's ties); nhũng tình cảm ấm nồng (warm sentiments); tình cảm của ho đang ấm dần lên (their emotions are warming up); sư quan tâm khiến người ta ấm lòng (cares that warm people's hearts), etc. By conceptualizing A HAPPY FAMILY IS A WARM HOUSE, Vietnamese people express the view that family is their beloved shelter, a place where people feel safe and can come back to feel comfortable, sentimental and loved.

\section{Conclusion}

In summary, based on the similar feelings of a house and a family, Vietnamese people use the cognition and experiences that are formed by their experiences of their houses to describe their family via the conceptual metaphor A FAMILY IS A HOUSE. Some aspects of the house, including the roof, pillar, space, building, being damaged, are mapped to family members, relationships, the establishment and breakup of the family to create lower-level metaphors of the conceptual metaphor A FAMILY IS A HOUSE, including: FATHER IS THE ROOF OF THE HOUSE, HUSBAND/ FATHER IS THE PILLAR OF THE HOUSE, RELATIONSHIPS AND LIFESTYLES OF THE FAMILY ARE THE SPACE OF THE HOUSE, ESTABLISHING AND KEEPING A FAMILY IS BUILDING A HOUSE, FAMILY BREAKUP IS A DAMAGED HOUSE. Besides, the house roof is also used to conceptualize family in the metaphor A HAPPY FAMILY IS A WARM HOUSE - a complex metaphor created by the combination of the conceptual metonymy THE HOUSE ROOF IS A HOUSE and the conceptual metaphor HAPPINESS IS WARMTH. The conceptual metaphor A FAMILY IS A HOUSE and its lower-level metaphors, derivative metaphors demonstrate the distinctive conceptualization of Vietnamese people about the family: A family is a place that shelters and protects people; a family is built up via a hard and timeconsuming process; family breakup causes lots of injuries to its members; in a family, the father holds the top position who leads the family and educates children; the father/husband is considered the strongest person who provides physical and spiritual supports to his wife and 
children; the relationships and lifestyles are the space embracing all family members; a happy family is a shelter full of warmth and love. As such, the conceptual metaphor A FAMILY IS A HOUSE and its lower-level metaphors illustrate the cares of Vietnamese people of their family including its establishment, structures, durability and functions.

\section{REFERENCES}

\section{Vietnamese}

Hoàng Phê (chủ biên). (2010). Tù điển tiếng Việt. Hà Nội: Nxb Từ điển bách khoa.

\section{English}

Adams, K. L. (2009). Conceptual Metaphors of Family in Political Debates in the USA. In K. Ahrens (Ed.), Politics, Gender and Conceptual Metaphors (pp. 184-206). London: Palgrave Macmillan.

Kövecses, Z. (2010). Metaphor - A Practical Introduction (2nd ed.). New York: Oxford University Press.

Lakoff, G. (1993). The Contemporary Theory of Metaphor. In A. Ortony (Ed.), Metaphor and Thought (2nd ed., pp. 202-251). Cambridge: Cambridge University Press.

Lakoff, G. \& Johnson, M. (1980). Metaphors we live by. London: The University of Chicago Press.

Rohrer, T. (2007). Embodiment and Experientialism. In D. Geeraerts and H. Cuyckens (Eds.), The Oxford Handbook of Cognitive Linguistics (pp. 25-47). New York: The University of Oxford Press.

Family. (n.d.). In Cambridge Dictionary. Retrieved from https://dictionary.cambridge.org/vi/dictionary/ english/family

\section{Survey data}

Phan Thị Vàng Anh (1994). Khi ngườ ta trẻ. Hà Nội: Nxb Hội Nhà văn.

Thái Cường (2018). Gam lam không thục. Tp HCM: Nxb Tổng hợp.

Vũ Đình Giang (2014). Nết đất. Tp HCM: Nxb Trẻ.

Trang Hạ (2014). Tình nhân không bao giờ đòi cuói (Tái bản lần thứ 7). Hà Nội: Nxb Phụ nữ.

Võ Thị Xuân Hà (2006). Chuyện của con gái người hát rong. Hà Nội: Nxb Hội Nhà văn.

Võ Thị Xuân Hà (2009). Thế giới tối đen. Hà Nội: Nxb Hội Nhà văn.

Phan Ngọc Diễm Hân (2012). Dấu xăm cánh buoóm. Tp Hồ Chí Minh: Nxb Trẻ.

Nguyễn Thị Thu Huệ (2004). 37 Truyện ngắn Nguyễn Thị Thu Huệ. Hà Nội: Nxb Hội Nhà văn.

Nguyên Hương (2014). 1989.vn. Tp HCM: Nxb Trẻ.
Nguyên Hương, Trang Hạ \& Nguyễn Thị Thanh Mận (2014). Món quà đến sau nhũng cơn mưa. Tp HCM: Nxb Trẻ.

Nguyễn Quỳnh Hương (2017). Trái tim đàn bà. Hà Nội: Nxb Phụ nữ.

Võ Thu Hương (2012). Đó là tình yêu. Tp HCM: Nxb Trẻ.

Nguyễn Xuân Khánh (2019). Chuyện ngõ nghèo. Hà Nội: Nxb Hội Nhà văn.

Trần Thị Ngọc Lan (2008). Mẹ trần gian. Hà Nội: Nxb Hội Nhà văn.

Từ Thiết Linh (2004). Miền quê trăn trỏ. Hà Nội: Nxb Hội Nhà văn.

Phạm Thị Ngọc Liên (2007). Người đàn bà bí ẩn. Tp HCM: Nxb Trẻ.

Phạm Thị Ngọc Liên (2015). Và tháng ngày trôi đi. Tp HCM: Nxb Trẻ.

Nguyễn Duy Năng (2012). Tản mạn tù quê ra tỉnh. Tp Vinh: Nxb Đại học Vinh.

Bích Ngân (2010). Thế giới xô lệch. Hà Nội: Nxb Hội Nhà văn.

Dạ Ngân (2010). Gánh đàn bà. Tp HCM: Nxb Thanh niên.

Dạ Ngân (2015). Hoa ở trong lòng. Hà Nội: Nxb Phụ nữ.

Dona Đỗ Ngọc (2017). ADN tình yêu. Hà Nội: Nxb Phụ nữ.

Đỗ Thị Minh Nguyệt (2013). Bũa tiệc trần gian. Hà Nội: Nxb Hội Nhà văn.

Nhiều tác giả (2011). Truyện ngắn hay và đoạt giải báo Phu nũ 2009 - Trả duyên. Hà Nội: Nxb Phụ nữ.

Nhiều tác giả (2014). Áo ảnh xanh xua. Tp HCM: Nxb Trẻ.

Ka Bình Phong (2017). Bũa đời lạc phận. Tp HCM: Nxb Trẻ.

Võ Diệu Thanh (2016). Qua mùa mặc nưa. Trong Tuyển tập truyện ngắn hay văn nghệ quân đội 2000-2016. Tp HCM: Nxb Trẻ.

Nguyễn Huy Thiệp (2007). Truyện ngắn Nguyễn Huy Thiệp. Sài Gòn: Nxb Văn hóa.

Hồng Thủy (2010). Mây trôi về phía cuối trời. Tp HCM: Nxb Trẻ.

Trần Đức Tĩnh (2014). Đối cực. Tp HCM: Nxb Trẻ.

Nguyễn Ngọc Tư (2017). Đong tấm lòng. Tp HCM: Nxb Trẻ.

Quang Trinh (tuyển chọn) (2011). Truyện ngắn đặc sắc 2011. Hà Nội: Nxb Thời đại.

Phan Ý Yên (2016). Không xinh, không thông minh, không bất bình thế giới. Hà Nội: Nxb Văn hóa Nghệ thuật. 


\title{
ẨN DỤ Ý NIỆM GIA ĐİNH LÀ NGÔI NHÀ TRONG TIẾNG VIẸT
}

\author{
Vũ Hoàng Cúc
}

Đại học Tây Nguyên, 567 Lê Duẩn, Buôn Ma Thuột, Đắk Lắk, Việt Nam NCS tại Trường Đại học Khoa học Xã hội và Nhân văn - Đại học Quốc gia Thành phố Hồ Chí Minh

Tóm tắt: Bài viết phân tích ẩn dụ ý niệm GIA ĐÌNH LÀ NGÔI NHÀ trong tiếng Việt nhằm tìm hiểu cách tri nhận của người Việt Nam về gia đình thông qua miền ý niệm NGÔI NHÀ. Để tiến hành việc nghiên cứu, bài viết sử dụng lý thuyết ẩn dụ ý niệm và các khái niệm cơ bản khác của Ngôn ngũ học tri nhận để xác lập và phân tích sự ánh xạ từ miền nguồn NGÔI NHÀ đến miền đích GIA ĐİNH. Kết quả nghiên cứu cho thấy rằng, người Việt Nam đã dùng ngôi nhà để khắc họa gia đình như là nơi che chở và bảo vệ mỗi thành viên. Bên cạnh đó, các bộ phận nóc nhà, mái nhà, tru (cột), không gian và hoạt động xây dưng, phá hủy ngôi nhà cũng được dùng để biểu hiện cách tư duy, nhận thức về vai trò của người cha, người chồng, mối quan hệ trong gia đình, sự hình thành và ly tán, sự che chở của gia đình. Việc dùng ngôi nhà để bày tỏ quan niệm về gia đình thể hiện đặc trưng văn hóa rất độc đáo trong cách tư duy của người Việt Nam.

Tù khóa: ẩn dụ ý niệm, ánh xạ, gia đình, ngôi nhà, tiếng Việt. 